\title{
Effect of Different Packaging Materials and Storage Temperatures on Storage Life of Tuberose (Polianthes tuberosa L.) cv. Bidhan Rajini - 1
}

\author{
J. Archana ${ }^{*}$, A. Girwani ${ }^{2}$, D. Vishnu Vardhan Reddy ${ }^{3}$ and C.H. Raja Goud ${ }^{4}$ \\ ${ }^{1}$ Department of Floriculture and Landscape Architecture, College of Horticulture, SKLTSHU, \\ Rajendranagar, Hyderabad-500030, India \\ ${ }^{2}$ Department of Floriculture and Landscape Architecture, College of Horticulture, SKLTSHU, \\ Mojerla, India \\ ${ }^{3}$ Department of Crop Physiology, College of Agriculture, PJTSAU, Hyderabad, India \\ ${ }^{4}$ Department of Entomology, College of Horticulture, SKLTSHU, Hyderabad, India \\ *Corresponding author
}

\section{A B S T R A C T}

In order to study the effect of different packaging materials [Polypropylene bags and LDPE bags at different grades of thickness (100 and 200 guage)] and storage conditions (ambient conditions, $4^{0} \mathrm{C}$ and $6^{\circ} \mathrm{C}$ ) on keeping quality of loose flowers

Keywords

Packaging material, Quality, Storage temperature and Tuberose

Article Info

Accepted:

17 June 2019

Available Online:

10 July 2019 of tuberose, fully developed unopened buds of tuberose loose flowers cv. Bidhan Rajini - 1 were harvested from the experimental plot early in the morning. It was observed that packaging significantly influenced Physiological loss in weight (PLW\%), relative water content (RWC\%), fifty percent wilting of flowers (days) and storage life (days) of flowers throughout the storage period. Among all the treatments, the loose flowers packaged in LDPE bags at 200 gauge and stored at $4^{0} \mathrm{C}$ has recorded the minimum physiological loss in weight $(0.656 \%)$, maximum relative water content $(86.15 \%)$ and maximum days for fifty percent wilting (17.6 days) and the flowers remained fresh for 21 days. Whereas the flowers without packaging and kept at ambient temperatures lost their shelf life within 2 days. In the present experiment beneficial effects of the combination of packaging and low temperature storage helped to create the modified atmospheric condition (low temperature and high relative humidity) and resulted to maintain a better quality flower for a longer time.

\section{Introduction}

Flowers are the most beautiful creation of the earth. Flowers symbolize beauty, purity, peace, love affection and honesty. Flowers have been associated with Indian art and culture from the time immemorial starting with the offering of flowers during worship by the ancient Rishis (sages). It is commercially cultivated in India in an area of about 2.43 lakh ha, with production of 15.45lakh MT of loose flowers and 6.91lakh stems of cut flower 
(NHB, 2016). Among the cut flowers produced, tuberose (Polianthes tuberosa Linn.), a member of family Amarayllidaceae, native to Mexico is one of the most important bulbous perennial crop grown in many tropical subtropical parts of the world and occupies a very selective and special position because of its beauty, elegance and sweet pleasant fragrance. Tuberose is also known as Glushaboo (Hindi), Rajanigandha (Bengali), Sukandaraji, Nelasapenji (Telegu), Nilasampanji (Tamil), Sugandharaja, Nelasamping or Sandharaga (Kanarese). Tuberose is commercially cultivated for cut and loose flower trade, and also it has long been cherished for aromatic oil extracted from its fragrant white flowers (Trueblood, 1973). Assam, Maharashtra, Gujarat, Haryana, Karnataka, Andhra Pradesh, Tamil Nadu, Uttar Pradesh, Uttrakhanda and Orissa are the major states where tuberose has become very popular. It is estimated that in India tuberose is commercially cultivated over 30,000 hectare area (Singh et al., 2010).

It is estimated that there is about $20 \%$ loss of tuberose occur during market. Due to their extreme perishable nature proper treatment is required to maintain the quality of tuberose (Hardenburg, 1990). However, lack of knowledge regarding proper post-harvest handling is one of the limiting factors in expansion of the trade and export of tuberose. Modified atmosphere packaging of fresh commodities is a successful technology for prolonging the post-harvest life during storage and marketing (Kader, 1986). One of the major benefits of modified atmosphere packaging (MAP) is the prevention or retardation of flower senescence and associated with physiological and biochemical changes (Sandhya, 2010).

Picking of individual flowers which grow at the horizontal position on the flower stalk is done early in the morning. Harvesting those in the previous evening and marketing in the next day leads to the weight loss of about 40 percent (Rameshwar, 1976). However, there are few reports on the studies of extension of loose tuberose flowers with the help of different packaging materials (Nagaraja et al., 1999a; Nagaraja et al., 1999b). Thus, the present investigation aimed to find out best packaging material for enhancing shelf life of tuberose loose flowers under Telangana condition so that the flowers can be available to the end users (consumers, oil extractors, decorators making floral ornaments and likewise) for longer duration. Therefore, keeping in mind, the above discussed factors regarding the tuberose flowers, present investigation was planned.

\section{Materials and Methods}

The lab experiment was laid out as Completely Randomized Design (CRD) in a factorial arrangement and replicated three times which was conducted at College of Horticulture, Rajendranagar, Hyderabad. For the experiment loose flowers of tuberose cv. Bidhan Rajini-1 were collected from an experimental plot of Floriculture research station, Rajendranagar. The experimental plot were well prepared by repeated tilling and application of organic manure (@5 kg/m2) and inorganic fertilizer (N: P: K @ 200: 200: 200/ ha).

A quantum of $60 \mathrm{~g}$ of flowers of the variety Bidhan Rajini-1 were harvested and packaged in two different packaging materials (PP and LDPE) of two different gauges (100 and 200 guage). The bags were sealed and stored at ambient conditions (room temperature), $4^{0} \mathrm{C}$ and $6^{\circ} \mathrm{C}$ (walk in cool chambers). The room temperature was $27 \pm 3^{\circ} \mathrm{C} \&$ relative humidity $60-80 \%$ during the experiment period. The experiment was designed in completely randomized design with factorial concept in three replications. In this study $35 \mathrm{~cm}$ x $25 \mathrm{~cm}$ 
sized bags of 100 gauge and 200 gauge thickness were used for packaging the tuberose flowers.

\section{Observations recorded}

Storage life of flowers was determined by the number of days for which the flowers remained fresh without losing the marketability and was expressed in days. And Days for $50 \%$ wilting of floret was recorded by visual observation and expressed in days. PLW was recorded at 3 days interval by using the below formula.

Initial flower weight -

Flower weight on day of observation

$\mathrm{PLW} \%=$

Initial flower weight X 100

Relative water content (RWC) was estimated by Whetherely method (1958) at 3 days interval by using the below formula.

$\operatorname{RWC}(\%)=\frac{\text { Fresh weight }- \text { Dry weight }}{\text { Turgid weight- Dry weight }}$

The collected replicated data was subjected to standard statistical analysis for Randomized Complete Block Design (RCBD) with Factorial concept (Panse and Sukhatme, 1985). Least significant difference was used to compare means and Critical Difference (C.D.) was used to compare for differences.

\section{Results and Discussion}

\section{Physiological loss in weight (PLW\%)}

The interaction effects between packages and storage temperatures (PxT) showed that the flowers packed in LDPE bags with 200 guage thickness (P4) and stored at temperature of $4^{0} \mathrm{C}$ (T1) recorded the low PLW during the entire period. Whereas flowers with no packaging (P0) and kept at $6^{\circ} \mathrm{C}(\mathrm{T} 2)$ recorded the maximum PLW. While the flowers without packaging stored at ambient conditions lost their shelf life in 2 days. The interaction effect of packing in LDPE bags with 200 guage and stored at $4^{0} \mathrm{C}$ temperature (P4T1) has recorded a significant decrease in the physiological loss in weight (PLW) of the flowers by creating a "passive modified atmospheric packaging (MAP) condition". Results are presented in Table 1.

Packaging maintains higher humidity, which slows down the process of moisture loss and proper balance of carbon dioxide and oxygen concentrations in turn reduces the process of respiration (Anzueto and Rizve 1985; Bhowmilk and Hulbert 1989) and this might be the reason for recording least PLW in LDPE bags with 200 guage thickness during the storage period. Further the cold storage $\left(4^{0} \mathrm{C}\right)$ has exerted a profound influence on the PLW and reduced the moisture loss from the flowers. This may be attributed to that, at lower temperatures, the respiration comes down and the flowers produce a lesser amount of ethylene (Bhattacharjee and De, 2005). The potentiality of the cold storage in reducing the PLW of the jasmine flowers was earlier documented by Thamaraiselvi et al., (2010).

\section{Relative water content (RWC \%)}

During the interaction (PxT) there is significant effect of packaging and storage temperatures on relative water content of flowers. Among interaction maximum RWC was recorded in the flowers packed in LDPE bags with 200 guage thickness (P4) and stored at temperature of $4^{0} \mathrm{C}(\mathrm{T} 1)$, whereas flowers kept outside with no packing lost there shelf life in 2 days. On $3^{\text {rd }}$ day maximum RWC $(86.15 \%)$ was recorded. By the $12^{\text {th }}$ day all the flowers kept at ambient conditions with different packing materials have lost their storage life. 
Table.1 Effect of different packaging materials and storage temperatures on physiological loss in weight (PLW\%) of tuberose flowers

\begin{tabular}{|c|c|c|c|c|c|c|c|c|c|c|c|c|}
\hline \multirow{4}{*}{$\begin{array}{l}\text { Packaging } \\
\text { material (p) }\end{array}$} & \multicolumn{12}{|c|}{ Days } \\
\hline & \multicolumn{4}{|c|}{ Day 3} & \multicolumn{4}{|c|}{ Day 6} & \multicolumn{4}{|c|}{ Day 9} \\
\hline & \multicolumn{3}{|c|}{ Temperature } & \multirow{2}{*}{$\begin{array}{l}\text { Packageing } \\
\operatorname{mean}\left(P_{i}\right)\end{array}$} & \multicolumn{3}{|c|}{ Temperature } & \multicolumn{2}{|l|}{ Packaging } & \multicolumn{2}{|c|}{ Temperature } & \multirow{2}{*}{$\begin{array}{l}\text { Packaging } \\
\text { mean }\left(P_{i}\right)\end{array}$} \\
\hline & $\mathbf{T}_{\mathbf{0}}$ & $\mathbf{T}_{1}$ & $\mathbf{T}_{2}$ & & $\mathbf{T}_{\mathbf{0}}$ & $\mathbf{T}_{1}$ & $\mathbf{T}_{2}$ & mean $\left(\mathbf{P}_{i}\right)$ & $\mathbf{T}_{0}$ & $\mathbf{T}_{1}$ & $\mathbf{T}_{2}$ & \\
\hline $\mathbf{P}_{0}$ & 0.00 & 18.66 & 20.66 & 13.11 & 0.00 & 0.00 & 0.00 & 0.00 & 0.00 & 0.00 & 0.00 & 0.00 \\
\hline $\mathbf{P}_{1}$ & 9.80 & 7.78 & 8.07 & 8.55 & 9.91 & 7.48 & 8.53 & 8.64 & 0.00 & 7.53 & 8.61 & 5.38 \\
\hline $\mathbf{P}_{2}$ & 2.75 & 5.22 & 5.88 & 4.61 & 3.24 & 3.46 & 3.15 & 3.28 & 0.00 & 5.19 & 7.31 & 4.16 \\
\hline $\mathbf{P}_{3}$ & 2.69 & 2.27 & 2.47 & 2.48 & 6.40 & 2.48 & 4.43 & 4.44 & 0.00 & 4.30 & 7.63 & 3.97 \\
\hline $\mathbf{P}_{4}$ & 0.92 & 0.65 & 0.86 & 0.81 & 2.24 & 1.07 & 1.92 & 1.74 & 2.82 & 1.31 & 1.98 & 2.04 \\
\hline $\begin{array}{l}\text { Temperature } \\
\text { mean }\left(\mathbf{T}_{\mathbf{i}}\right)\end{array}$ & 3.23 & 6.92 & 7.59 & & 4.36 & 2.90 & 3.60 & & 0.56 & 3.67 & 5.10 & \\
\hline
\end{tabular}

\begin{tabular}{|l|c|c|c|c|c|c|}
\hline & SEm \pm & CD at 5\% & SEm \pm & CD at 5\% & SEm \pm & CD at 5\% \\
\hline Packaging & 0.34 & 1.00 & 0.32 & 0.94 & 0.18 & 0.54 \\
\hline Temperature & 0.27 & 0.78 & 0.25 & 0.73 & 0.14 & 0.41 \\
\hline Packaging $x$ & 0.60 & 1.74 & 0.56 & 1.63 & 0.32 \\
\hline temperature & & & & & \\
\hline
\end{tabular}

0.00 - Indicates flowers have lost their storage life.

Packaging materials: P0- No packaging, P1- Polypropylene bags with 100 guage thickness, P2- Polypropylene bags with 200 guage thickness, P3-Low density poly ethylene bags with 100 guage thickness, P4- Low density poly ethylene bags with 200 guage thickness.

Storage temperatures: T0- Ambient conditions T1- $4^{0} \mathrm{C}$ T2- $6^{0} \mathrm{C}$

Table.1 Cont. 


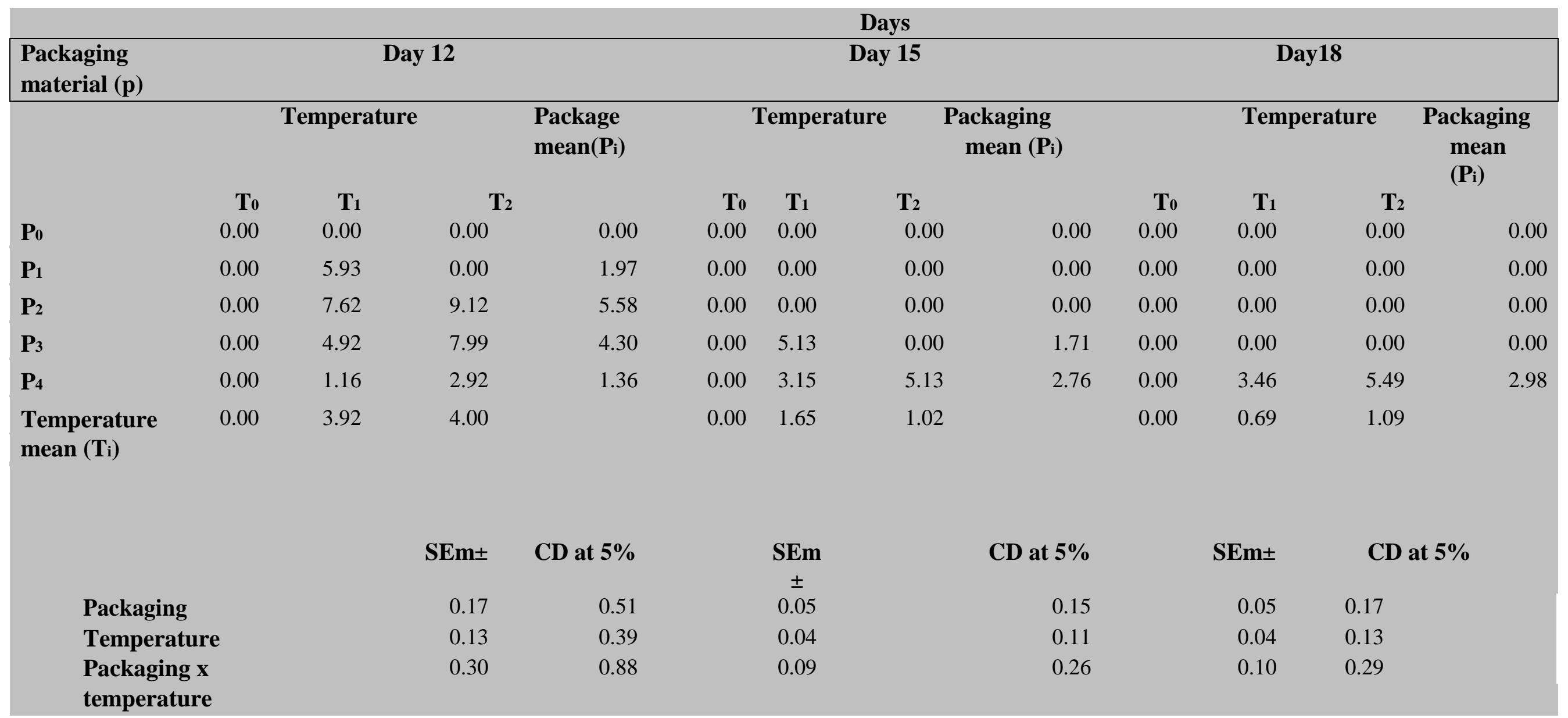

0.00 - Indicates flowers have lost their storage life.

Packaging materials: P0- No packaging, P1- Polypropylene bags with 100 guage thickness, P2- Polypropylene bags with 200 guage thickness, P3-Low density poly ethylene bags with 100 guage thickness, P4- Low density poly ethylene bags with 200 guage thickness.

Storage temperatures: T0- Ambient conditions T1- $4^{0} \mathrm{C}$ T2- $6^{0} \mathrm{C}$ 
Table.2 Effect of different packaging materials and storage temperatures on Relative water content (RWC\%) of tuberose flowers

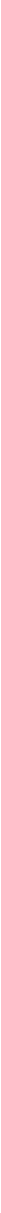

0.00 - Indicates flowers have lost their storage life.

Packaging materials: P0- No packaging, P1- Polypropylene bags with 100 guage thickness, P2- Polypropylene bags with 200 guage thickness, P3-Low density poly ethylene bags with 100 guage thickness, P4- Low density poly ethylene bags with 200 guage thickness.

Storage temperatures: T0- Ambient conditions $\mathrm{T} 1-4^{\circ} \mathrm{C} \quad \mathrm{T} 2-6^{\circ} \mathrm{C}$ 
Table.2 Cont.

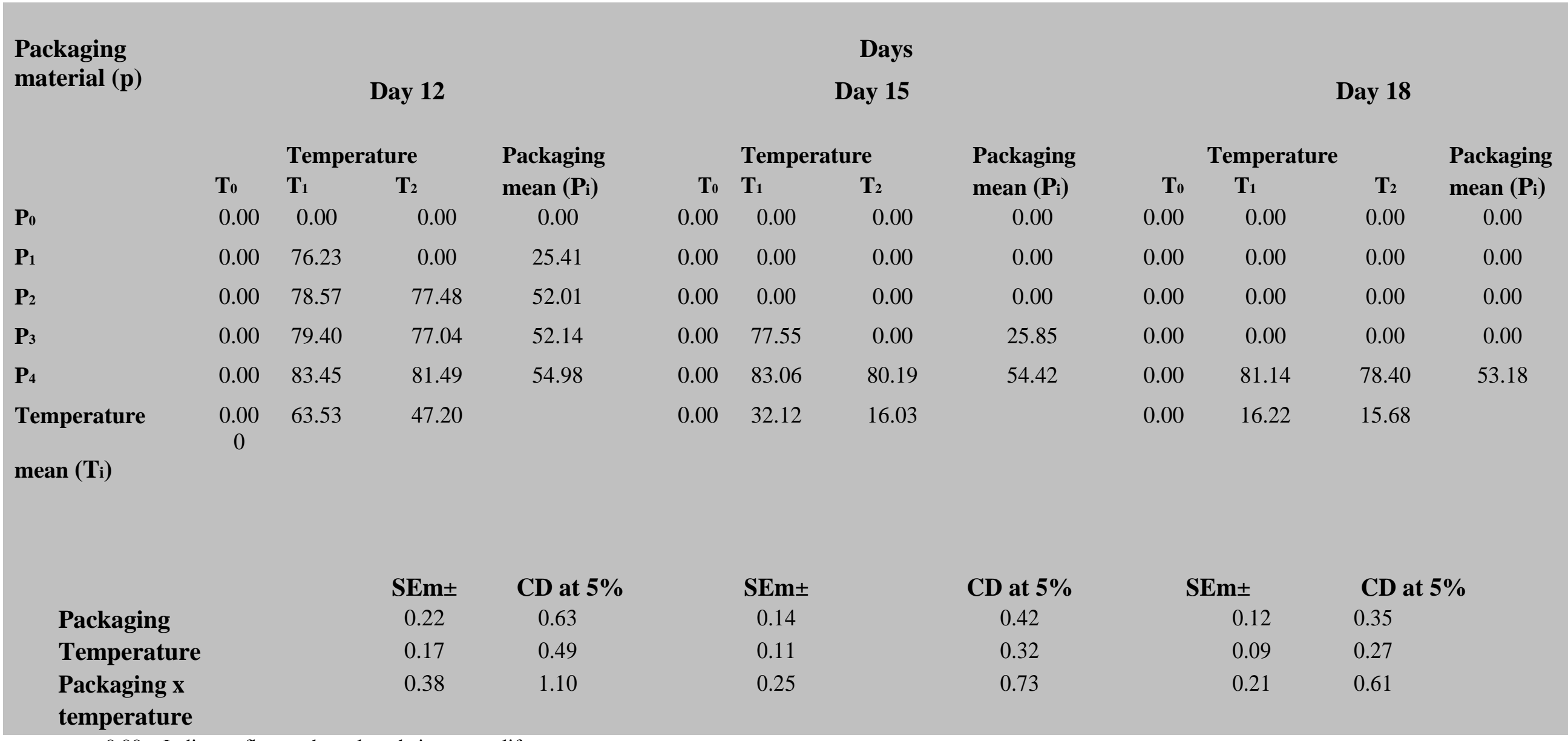

0.00 - Indicates flowers have lost their storage life.

Packaging materials: P0- No packaging, P1- Polypropylene bags with 100 guage thickness, P2- Polypropylene bags with 200 guage thickness, P3-Low density poly ethylene bags with 100 guage thickness, P4- Low density poly ethylene bags with 200 guage thickness.

Storage temperatures: T0- Ambient conditions T1- $4^{0} \mathrm{C} \quad \mathrm{T} 2-6^{0} \mathrm{C}$ 
Table.3 Effect of different packaging materials and storage temperatures on $50 \%$ flower wilting (days) of tuberose flowers

\begin{tabular}{|c|c|c|c|c|}
\hline \multirow{3}{*}{ Packaging material (p) } & \multicolumn{3}{|c|}{ Days } & \multirow{3}{*}{$\begin{array}{l}\text { Package } \\
\text { mean }\left(\mathbf{P}_{\mathbf{i}}\right)\end{array}$} \\
\hline & \multicolumn{3}{|c|}{ Temperatur } & \\
\hline & $\mathbf{T}_{\mathbf{0}}$ & $\mathbf{T}_{\mathbf{1}}$ & $\mathbf{T}_{2}$ & \\
\hline $\mathbf{P}_{0}$ & 1.16 & 3.00 & 2.33 & 2.16 \\
\hline $\mathbf{P}_{1}$ & 3.66 & 8.66 & 7.33 & 6.55 \\
\hline $\mathbf{P}_{2}$ & 5.00 & 11.6 & 10.0 & 8.88 \\
\hline $\mathbf{P}_{3}$ & 5.00 & 13.6 & 10.6 & 9.77 \\
\hline $\mathbf{P}_{4}$ & 6.33 & 17.6 & 15.0 & 13.0 \\
\hline \multirow[t]{2}{*}{ Treatment mean $\left(\mathbf{T}_{\mathbf{i}}\right)$} & 4.23 & 10.9 & 9.06 & \\
\hline & \multicolumn{3}{|c|}{$\operatorname{SEm} \pm$} & CD at $5 \%$ \\
\hline \multicolumn{2}{|l|}{ Packaging } & \multicolumn{2}{|c|}{0.26} & 0.75 \\
\hline \multicolumn{2}{|l|}{ Temperature } & \multicolumn{2}{|c|}{0.20} & 0.58 \\
\hline \multicolumn{2}{|c|}{ Packaging $\mathrm{x}$ temperature } & \multicolumn{2}{|c|}{0.45} & 1.31 \\
\hline
\end{tabular}

Packaging materials: P0- No packaging, P1- Polypropylene bags with 100 guage thickness, P2- Polypropylene bags with 200 guage thickness, P3-Low density poly ethylene bags with 100 guage thickness, P4- Low density poly ethylene bags with 200 guage thickness.

Storage temperatures: T0- Ambient conditions T1- $4^{0} \mathrm{C}$

T2- $6{ }^{0} \mathrm{C}$ 
Table.4 Effect of different packaging materials and storage temperatures on storage life (Days) of tuberose flowers

\begin{tabular}{|c|c|c|c|c|}
\hline \multirow{3}{*}{ Packaging material (p) } & \multicolumn{4}{|c|}{ Days } \\
\hline & \multicolumn{3}{|c|}{ Temperature } & \multirow{2}{*}{$\begin{array}{l}\text { Package } \\
\text { mean }\left(P_{i}\right)\end{array}$} \\
\hline & $\mathbf{T}_{0}$ & $\mathbf{T}_{1}$ & $\mathbf{T}_{2}$ & \\
\hline $\mathbf{P}_{0}$ & 2.00 & 4.66 & 3.66 & 3.44 \\
\hline $\mathbf{P}_{1}$ & 5.66 & 12.00 & 10.00 & 9.22 \\
\hline $\mathbf{P}_{2}$ & 7.00 & 14.00 & 13.00 & 11.33 \\
\hline $\mathbf{P}_{3}$ & 7.00 & 16.00 & 13.00 & 12.00 \\
\hline $\mathbf{P}_{4}$ & 9.00 & 21.00 & 18.00 & 16.00 \\
\hline Treatment mean $\left(\mathbf{T}_{\mathbf{i}}\right)$ & 6.13 & 13.53 & 11.53 & \\
\hline
\end{tabular}

\begin{tabular}{|l|c|c|}
\hline & SEm \pm & CD at 5\% \\
\hline Packaging & 0.07 & 0.21 \\
\hline Temperature & 0.05 & 0.16 \\
\hline Packaging $\mathbf{x}$ temperature & 0.12 & 0.36 \\
\hline
\end{tabular}

Packaging materials: P0- No packaging, P1- Polypropylene bags with 100 guage thickness, P2- Polypropylene bags with 200 guage thickness, P3-Low density poly ethylene bags with 100 guage thickness, P4- Low density poly ethylene bags with 200 guage thickness.

Storage temperatures: T0- Ambient conditions T1- $4^{0} \mathrm{C}, \mathrm{T} 2-6^{0} \mathrm{C}$

On this day maximum RWC (83.45\%) was recorded in flowers packed in LDPE bag with 200 guage thickness and stored at temperature of $4^{\circ} \mathrm{C}$ (P4T1). Whereas minimum $(76.23 \%)$ in the flowers packed in PP bags with 100 guage thickness and stored at temperature of $4^{0} \mathrm{C}$ (P1T1). By the $18^{\text {th }}$ day all the flowers have lost there shelf life except the flowers packed in LDPE 200 guage thickness (P4) and stored at temperatures of $4^{\circ} \mathrm{C}(\mathrm{T} 1)$ and $6^{0} \mathrm{C}$ (T2). Results are presented in Table 2. Regarding the interaction effect of LDPE bags with 200 guage thickness stored at cold storage conditions, the non-permeability property of the polyethylene bags to moisture
(Ravi et al., 2004) and reduced respiration rate and low moisture loss from the flowers due to cold storage might have resulted in the flowers to record the minimum PLW and to remain turgid for a longer time without losing moisture early. Due to this, the flower petals recorded the more turgid weight when soaked in distilled water resulting in the maximum RWC of the flowers.

\section{Fifty percent flower wilting (Days)}

Maximum days (17.6 days) for fifty percent wilting was recorded in the flowers stored at $4^{0} \mathrm{C}$ (T1) and packed in (P4) LDPE bag with 
200 guage thickness (P4T1). And minimum days (1.16days) (P0T0) observed in the flowers kept at ambient conditions (T0) and kept without packing (P0). Results are presented in Table 3. Further, packaging and the cold storage has delayed the petal wilting as well as the senescence of the flowers. In case of the control flowers, the increased PLW led to the decline in fresh weight and wilting ultimately resulting in the early senescence of the flowers as reported in cut gerberas by Gerasopoulos and chebli (1999).

\section{Storage life of flowers (days)}

Maximum days (21.0 days) of storage (P4T1) was recorded in the flowers packed in LDPE bag with 200 guage thickness (P4) and stored at $4^{0} \mathrm{C}$ temperature (T1). Whereas minimum days (2.0 days) of shelf life was recorded by the flowers (P0T0) without packing (P0) and stored at ambient conditions (T0). Results are presented in Table 4. Packaging of tuberose florets in LDPE has enhanced shelf life. This effect is primarily due to initially continued metabolic activities specially respiration and transpiration of flowers, might have led to the evolution of beneficial equilibrium of modified atmosphere with high $\mathrm{CO} 2$ and low $\mathrm{O} 2$ and high relative humidity within the package. The flowers without packaging recorded more moisture loss from the flowers owing to the increased ventilation this resulted in more loss of fresh weight of flowers (Saidulu, 2013). And the flowers are stored at low temperatures, they remained turgid and recorded reduced moisture loss and increased shelf life.

It is concluded from the above experiment that the flowers packed in LDPE bags with 200 guage thickness and stored at $4^{0} \mathrm{C}$ has recorded the minimum PLW, maximum RWC, days for fifty percent flower wilting, and with a storage life of 21 days compared to flowers without packing. The tuberose flowers stored under ambient temperatures lost there storage life within 2 days.

\section{References}

Anzueto, C.R. and Rizvi, S.S.H. 1985. Individual packaging of apples for shelf life extension. Journal of Food Science. 50: 897-900 \& 904.

Bhattacharjee, S.K. and De, L.C. 2005. PostHarvest Technology of Flowers and Ornamental Plants. Pointer Publishers, 87-97.

Bhowmilk, S.R. and Hulbert, G.J. 1989. Effect of individual shrink wrapping on shelf life, lasting quality and respiration rate of tomatoes. Laben millet Wisconschart unde technologie. 22: 119-123.

Gerasopoulos, D. and Chebli, B. 1999. Effect of pre- and postharvest calcium applications on the vase life of cut gerberas. Journal of Horticultural Science \& Biotechnology. 74(1): 78-81.

Hardenburg, R.E. 1990. The commercial storage of fruits, vegetables, and florist and nursery stocks. USDA Agriculture Handbook pp 66.

Kader, A.A. 1986. Modified atmosphere packaging (MAP) for long-term shipment of cut flowers. Acta Hortculturea. 553: 631-634.

Nagaraja, G.S., Gowda, J.V.N. and Farooqi, A.A. 1999a. Influence of chemicals and packaging on the shelf life of tuberose flowers. Karnataka Journal of Agricultural Sciences. 12(1/4): 132-136. Nagaraja, G.S., Gowda, J.V.N. and Farooqi, A.A. 1999b. Shelf life of tuberose flowers as influenced by packaging and ventilation. Karnataka Journal of Agricultural Sciences. 12(1/4): 239-242.

National Horticulture Board Data Base. 20152016. http//www.nhb.gov.in.

Panse, V.G., Sukhatme, P.V. 1954. Statistical methods for agricultural workers. 
ICAR: Indian Agricultural Research Institute. 519 (1): 63

Rameshwar, A. 1976. Tuberose cultivation around Bangalore. Indian Horticulture. 21:22-23.

Saidulu.Y.2013. Effect of pre harvest foliar sprays, packaging and storage temperatures on growth, yield and storability of African marigold (Tagetes erecta L.) cv. pusa narangi gainda. M.Sc.thesis submitted to Dr. Y.S.R Horticultural University, Venkataramannagudem.

Sandhya. 2010. Effect of Pre- and Postharvest treatment on flower longevity of tuberose. Acta Horiculturea. 482: 83-87. Sandhya. 2010. Effect of Pre- and Postharvest treatment on flower longevity of tuberose. Acta Horiculturea. 482: 83-87.
Singh, P.K., Kadam, G.B. and Jyoti, R. 2010. Production Manual on Tuberose (Polianthes tuberose L.) pp.1-2. Singh, P.K., Kadam, G.B. and Jyoti, R. 2010. Production Manual on Tuberose (Polianthes tuberose L.) pp.1-2.

Thamarai Selvi, S.P, Chezhiyan, N. and Ramar, A. 2002. Studies on the effect of growth regulators, calcium, boron and organics on rose. South Indian Horticulture. 50(4-6): 430-436

Trueblood, E.W.E. 1973. The tuberose (Polianthes tuberose L.) Economic Botany. pp. 27: 157.

Weatherely, P.E. and Barrs, M.D. 1962. A reexamination of relative turgidity for estimating water deficit in leaves. Australian Journal of Biological Sciences. 15: 413-428.

\section{How to cite this article:}

Archana, J., A. Girwani, D. Vishnu Vardhan Reddy and Raja Goud, C.H. 2019. Effect of Different Packaging Materials and Storage Temperatures on Storage Life of Tuberose (Polianthes tuberosa L.) cv. Bidhan Rajini - 1. Int.J.Curr.Microbiol.App.Sci. 8(07): 23752385. doi: https://doi.org/10.20546/ijcmas.2019.807.291 